\title{
A late modernist
}

Edwin Holgate

Curators: Rosalind Pepall with Brian Foss Montreal Museum of Fine Arts

Until Oct. 2, 2005

\section{T} There is a portrait of a child-woman clad in black hanging in the $\mathrm{Na}$ tional Gallery in Ottawa that I regularly visit. Her head, poised slightly off centre, heightens the intensity of her sorrowful eyes and taut neck muscles, while the black of her dress and hair contrast with the aqua background and the youthful volume of her flesh. This compelling image by Edwin Holgate (1892-1977), the eighth member of the Group of Seven, is included the first major retrospective of his work, now on view at the Montreal Museum of Fine Arts. Ludivine (1930) is but one of many highlights in an exhibition that pays homage to Holgate's traditional roots and modern preoccupation with "form, form, form."

It's apt that Edwin Holgate, which features 165 works from 54 collectors, has begun its four-city tour in Montréal, where Holgate was a popular teacher (his pupils included Jean Paul Lemieux and Stanley Cosgrove). Holgate spent most of his life in that city as a quiet presence in the art community, encouraging younger artists and co-founding several arts organizations.

Holgate came late to the Group of Seven, joining in 1929 and participating in only two shows before it disbanded around 1932. But his work found the same sustenance in landscape and nature, and he shared the Group's modernist concerns with form, structure, colour and volume. But where Holgate differed from most of the other members (aside from Fred Varley) was in his preoccupation with portraits and figures.

The exhibition follows a more or less chronological course, beginning with Holgate's first sojourn in Paris (1912-14) and his time as a soldier in World War I . Over the Top (c. 1918) is a remarkably modernist painting from this early period, featuring a cluster of black figures emerging from a trench under a piercing blue night sky punctuated by three flares that could just as well be guiding stars.

After the war, Holgate returned to Paris and studied for a time under the avant-garde artist Adolf Milman, who emphasized drawing and colour. Holgate emerged an expert draughtsman - his red and black chalk Portrait Study (1924) of an older man recalls the masters - and a sophisticated modern portrait painter. Suzy (1921) is sharply outlined in black a signature of his work while short, angular brushstrokes build texture and a startling volume, particularly on her forearm where one can "see" the fine hairs.

On his return to Montréal, Holgate rejoined the city's intellectual and artistic milieu. Encouraged by Group members, he began painting quintessential Canadian figures, beginning with The Lumberjack (1924). These were not commissioned portraits - a point Holgate made by not naming most of the people, though he knew many well — and thus he was able to interpret his subjects freely. Holgate was a methodical, careful and, some would say, dispassionate painter; his subjects typically have little facial expression. Yet his canvases are remarkably emotive. Their simplicity, the sculptural use of form and light, stripped-down backgrounds and the limited chromatic range creates and amplifies an impression. In Paul, Trapper (1929), for example, nearly all anecdotal detail is gone, lending the sitter a monumental presence. Ludivine, meanwhile, resonates with sadness, reflecting the fact that this 15-yearold's mother had recently died, leaving her in charge of numerous siblings.

In 1926 A.Y. Jackson invited Holgate on a month-long trip to British Columbia's Skeena River. There, Holgate painted Northwest coastal scenes, tackling essentially the same subject matter as Emily Carr; in contrast to her spiritual renderings, however, his paintings take their cue from the formalism of Cézanne.

Holgate's modernist composition continued to evolve through his Quebec landscapes, which predominately depicted the areas around Mont Tremblant in the Laurentians and Natashquan on the lower north shore of the St. Lawrence. The elongated trees in Blackberry Island, Lac Tremblant (c. 1934) are very much in the Group's tradition, but their black outlining lends the solidity that Holgate 


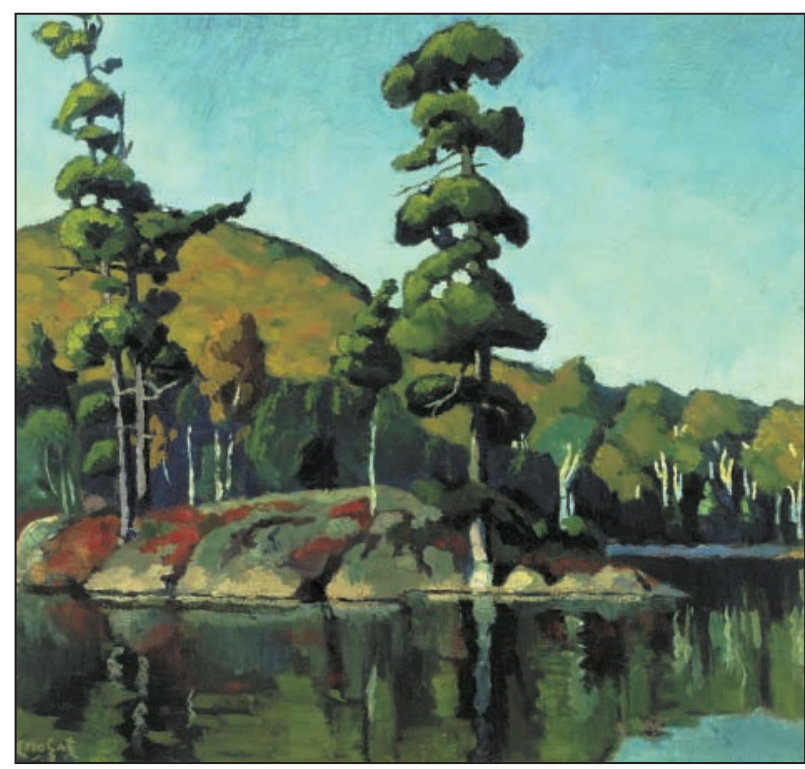

Edwin Holgate, Blackberry Island, Lac Tremblant (circa 1934). Oil on canvas. $31.8 \mathrm{~cm} \times 34.3 \mathrm{~cm}$. Collection of Rod and Catherine Mackenzie.

demanded of his work. Great Bug Pond, Cachée River (1939) is even more stylized, with its conical trees and zigsaw islands.

But it is in his resplendent nudes, such as The Bathers (1937), where Holgate offers an innovative variation on the landscape aesthetic with bodily forms that echo the contours of the Canadian landscape. It was during the 1930s that Holgate also created some of his most poignant portraits. Curé of Natashquan (1931) typifies his sophisticated style with a multi-faceted sculpting of the face, contrasts of light and dark and a simple background. The Head (1938), the most stylized of these portraits, depicts his wife, Frances Rittenhouse, who had donned a headscarf to do her housecleaning. The image is an exercise in pure form using a limited palette of burgundy, brown and off-white.

For twelve years during this time (1922-1934), Holgate was also preoccupied with printmaking and received considerable recognition for his wood engravings, which included a series of 23 illustrations depicting Quebec rural life for the English translation of Georges Bouchard's Vielles choses, vieille gens (1928). (The book is now forgotten, but not Holgate's prints.) Holgate, who never wrote about his paintings, wrote of his prints that he liked the "crisp whites and rich blacks." The Stairway (1930), considered by some as Holgate's finest print, depicts his wife Frances climbing stairs at night, with pure white delineating the stark black of the banister and railings, while detailed texture characterizes the shadows.

At the peak of his productivity and reputation as a founding member of the Canadian Group of Painters (the successor to the Group of Seven), Holgate became an official war artist during World War II. He never saw action, but instead visited shipyards in Sorel, Que., and two Canadian air force bases in England. The two paintings from Sorel are geometrical, almost avant-garde in their approach, but the paintings from the base are the weakest in this exhibition. Holgate reportedly found overseas working conditions difficult and after only seven months was sent home. The subject matter of planes and tiny figures was alien to him; form alone was insufficient to redeem these works, with a few exceptions. The Dispersal Hut (1944) gives an emotional sense of the tedium of waiting that is integral to warfare, and his portraits demonstrate his fine draughtsmanship. But Holgate recognized the limitations of his output: "I am not proud of what I have done," he wrote to the government. Taken in this context, it's surprising that so many of these paintings are included in this retrospective - an inclusion that has led some critics to remark on the uneven quality of his work. Rather, his failed wartime effort may say more about the constraints of the official war artists program than about Holgate's abilities.

Returning to Montréal, Holgate found a brave new art world that excluded his aesthetic concerns. In a letter to a Hamilton curator, Holgate wrote that he felt his work was "pretty dull for the people who go for abstraction and psychological warfare in their arts. ... I feel that doodling is for the telephone pad - and for one genuine and good abstraction - we have fifty phonies hanging onto the bandwagon." In 1946 he retreated to Morin Heights in the Laurentians, where he all but abandoned figure painting to concentrate on landscape. Not that you would know this from the present exhibition, which includes portraits in the concluding room that were painted decades earlier, and only a few works from this later era. Notable among them for its structure and balance is the critically acclaimed Laurentian Cemetery (1949).

Holgate lived a full artistic life, progressing, exploring other media, teaching, founding organizations and finally refining his vision of landscape painting. He made a significant contribution as a nurturer of Canadian art and artists, an intellectual and a modern artist. Perhaps his only limitation was that he was born too late. In the end, he was a lone figure, straddling traditionalist and modernist concerns when the art world had moved on.

\section{Barbara Sibbald \\ CMAF}

\section{Reference}

1. Pepall R. An art of vigour and restraint. In Pepall R, Foss B, editors. Edwin Holgate [exhibition catalogue]. Montréal: Montreal Museum of Fine Arts; 2005. p. 24.

\section{Exhibition itinerary:}

\section{Glenbow Museum, Calgary}

Mar. 11- June 4, 2006

The McMichael Canadian Art Collection

Kleinberg, Ont.

June 24 - Sept. 16, 2006

National Gallery of Canada, Ottawa

Oct. 6, 2006 - Jan. 7, 2007

Beaverbrook Art Gallery, Fredericton, NB Jan. 21- Apr. 15, 2007 